\title{
Verb-Clitic Structures in Eivissan Catalan: Recursive Prosodic Words and Allomorphy*
}

\author{
Francesc Torres-Tamarit \\ SFL, Université Paris 8, CNRS \\ francescjosep.torres@cnrs.fr \\ Eulàlia Bonet \\ Universitat Autònoma de Barcelona \\ eulalia.bonet@uab.cat
}

Received: December 10, 2018

Accepted: May 17, 2019

\begin{abstract}
This paper deals with stress shift in verb-clitic structures in Eivissan Catalan, an understudied Romance variety. Within Balearic Catalan, this is the only subdialect in which stress shift is restricted to apply only in second conjugation pre-clitic infinitives, those that, as opposed to other conjugations, have penultimate stress when they are pronounced in isolation. Stress in second conjugation infinitives in Eivissan Catalan shifts one syllable to the right, that is, to the final syllable of the verbal stem, when one or more pronominal enclitics follow. There is no stress shift in pre-clitic imperatives. We claim that pronominal enclitics in Eivissan Catalan adjoin to a recursive, maximal prosodic word, and that the domain for stress assignment is the minimal, embedded prosodic word. We further analyze two cases of stress-conditioned allomorphy (i.e. allomorphy of the infinitive morph and allomorphy of the verbal root) that occur in infinitive-clitic structures.
\end{abstract}

Keywords: allomorphy; clitic; Eivissan Catalan; prosodic word; recursivity; stress shift

Resum. Les estructures verb-clític en eivissenc: mots prosòdics recursius i al·lomorfia

Aquest treball investiga el desplaçament accentual en estructures verb-clític en eivissenc, una varietat romànica poc estudiada. Dintre del balear, aquest és l'únic subdialecte en el qual el desplaçament accentual només afecta infinitius de la segona conjugació seguits de clític, és a dir, els que, en contrast amb altres conjugacions, tenen accent a la penúltima síl laba quan no van seguits de clític. En eivissenc, quan el verb va seguit d'un o més enclítics pronominals, l'accent dels infinitius de la segona conjugació es desplaça una síl laba cap a la dreta, que és l'última síl·laba del radical verbal; no hi ha desplaçament quan els clítics van precedits d'un imperatiu. Proposem

* This work received support from grant FFI2016-76245-C3-1-P (Agencia Estatal de Investigación, AEI, and Fondo Europeo de Desarrollo Regional, FEDER), and, for Bonet, from Generalitat de Catalunya, grant 2017 SGR 634. We want to thank Donca Steriade and Joan Mascaró for discussion of the data and possible analyses, as well as two anonymous reviewers for their comments on the first version of this paper. 
que els enclítics pronominals de l'eivissenc s'adjunten a un mot prosòdic recursiu màxim i que el domini d'assignació d'accent és el mot prosòdic mínim, subordinat. També analitzem dos casos d'al·lomorfia motivada per l'accent, que es troba en les estructures infinitiu-clític, al·lomorfia que afecta el morf d'infinitiu i al·lomorfia que afecta l'arrel verbal.

Paraules clau: al·lomorfia; clític; eivissenc; mot prosòdic; recursivitat; desplaçament accentual

\title{
Table of Contents
}

\author{
1. Introduction 5. Conclusions \\ 2. Data References
}

3. Analysis

4. Allomorphy in infinitive-clitic structures in Eivissan Catalan

\section{Introduction}

The domain for stress assignment generally corresponds to lexical words, that is, roots plus their affixes, which in prosodic phonology are said to map onto prosodic words. Morphosyntactic constituents larger than one lexical word do not usually correlate with prosodic domains for stress assignment (but see Kaisse 2017 for cases in which stress assignment can span over two lexical words when both occur as frequent collocations in Macedonian). One exception to this generalization is the behavior of clitics, a phonological term referring to function words that depend prosodically on lexical words, their prosodic hosts. In such cases, the domain for stress assignment can be larger than the strict lexical word as it includes clitics. Selkirk (1995) and Peperkamp (1997) (and later Itô \& Mester 2009) have shown that clitics prosodify with their hosts in a variety of ways that generate a continuum that ranges from more cohesive to less cohesive host-clitic structures. The ways in which clitics prosodify with their hosts has an impact on stress assignment, and studying the stress patterns of host-clitic structures therefore contributes to a better understanding of the general principles governing stress assignment, particularly of the prosodic domains in which it applies. Pronominal clitics in Romance offer a rich empirical domain for studying stress assignment in structures containing enclitics (see Repetti 2016 for an overview and for previous works cited therein). The goal of this paper is to investigate the prosodic and morphological properties of verb-clitic structures in Eivissan Catalan, which has received no attention in the literature so far. In Catalan, pronominal clitics are encliticized to imperatives and infinitives (and also gerunds). Eivissan Catalan is of interest here because it exhibits a highly restrictive case of enclitic-induced stress shift that has not been attested before. In Eivissan Catalan, stress shift is restricted to occur only in penultimately-stressed

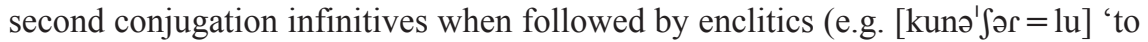

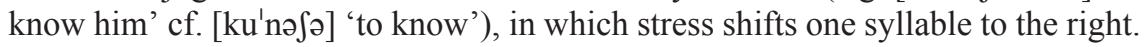


When second conjugation infinitives are pronounced in isolation the locus of stress is the penultimate syllable of the verb, while with enclisis clitics remain unstressed but the stress shifts to the last syllable of the verb, even in the presence of enclitic clusters in which there would be enough phonological material to build a metrical foot on top of the clitics (e.g. [mərə' $\int \partial r=$ tə $=$ ləs] 'to deserve them yourself' cf. [mə'rəðə] 'to deserve'). The pattern of stress shift in Eivissan Catalan deviates from the patterns of stress shift found in all the other subdialects of Balearic Catalan (Torres-Tamarit \& Pons-Moll 2019), and is therefore valuable for establishing a more solid typology of pronominal encliticization in Romance. The main claim of this paper is that prosodic categories such as the prosodic word can be hierarchically self-embedded (see Bennett 2018 and works cited therein for arguments in favor of recursive prosodic categories), and that enclitics in Eivissan Catalan adjoin to a recursive prosodic word that lies outside the domain of stress assignment, which is restricted to minimal prosodic words. A process of word-final $/ \mathrm{f} /$ deletion that affects infinitives will also be discussed that gives support to an analysis of stress shift based on recursive prosodic words and that goes against positing additional prosodic categories such as the clitic group (Vogel 2009) or the prosodic word group (Vigário 2010). Second conjugation infinitives with enclitics in Eivissan Catalan further exhibit an interesting case of allomorph selection of one of the two available infinitive morphs, as well as a case of verbal root allomorphy. Allomorph selection in infinitives followed by enclitics has not been reported before and constitutes an interesting case of phonologically-conditioned allomorphy (see Bonet \& Torres-Tamarit 2010, 2011 for cases of allomorphy in imperatives followed by enclitics in Balearic Catalan).

The remainder of this paper is organized as follows. In section 2 we describe the stress patterns found in verb-clitic structures in Central Catalan and Balearic Catalan: Majorcan, Minorcan, Formenteran, and Eivissan. In section 3 we briefly review Itô \& Mester's (2009) previous approach to the prosodification of clitics, and provide an OT analysis of verb-clitic structures in Eivissan Catalan. Section 4 describes the allomorphic alternations found in infinitive-clitic structures with respect to isolated infinitives in Eivissan Catalan and proposes an OT analysis of the data based on the lexical ordering of second conjugation infinitive allomorphs (Mascaró 2007). Section 5 concludes the paper.

\section{Data}

\subsection{Stress in verb-clitic structures in Catalan}

Balearic Catalan is a dialect of Catalan that is further subdivided into Formenteran, Eivissan, Majorcan and Minorcan Catalan (each island of the Balearic archipelago having its own subdialect). Whereas Majorcan, Minorcan and, more recently, Formenteran Catalan have received some attention in the literature (see TorresTamarit \& Pons-Moll 2019 and previous references cited therein), the phonology of pronominal enclitics in Eivissan Catalan is understudied. New data on Eivissan Catalan are presented in this paper (see also Marí Tur 2017 and Ribas Tur 2018). From a theoretical point of view, these data give new evidence in favor of pho- 
nologically optimizing stress shift in verb-clitic structures, as well as recursive prosodic words.

In Majorcan and Minorcan Catalan, stress always shifts to the last syllable of the whole verb-clitic structure. Therefore, the location of stress in a verb-clitic structure always differs from the location of stress when the verb is pronounced in isolation. ${ }^{1}$ Stress shifts irrespective of the conjugational class of the verb, the morphosyntactic features of the clitic(s), whether the verb is an imperative or an infinitive, and whether there is one or more clitics. Some examples of stress shift in Majorcan Catalan appear in (1) with one enclitic in $(1 \mathrm{a}, \mathrm{b})$ and two enclitics in (1c). Vowel reduction to schwa in the verb further demonstrates that stress shifts in forms with enclisis (see also Nadeu et al. 2016). The same stress patterns are found in Minorcan Catalan, not exemplified in (1).

(1) Stress shift in Majorcan Catalan
a. IMP. $2 \mathrm{SG} \quad \mathrm{IMP} .2 \mathrm{SG}=3 \mathrm{SG} . \mathrm{F} . \mathrm{ACC}$
['kantə] [kəntə='lo]
'sing!' 'sing it!'
b. IMP.2PL IMP.2PL $=3$ SG.DAT
[kən'taw] [kəntəw $=$ 'li]
'sing!' 'sing to him/her!'
c. INF. INF=3SG.F.ACC $=1 \mathrm{SG}$
[kən'ta] [kəntəl $=\mathrm{l} b=$ 'mə]
'to sing' 'to sing it to me'

In Formenteran Catalan, by contrast, stress is not shifted to one and the same position. Instead, stress shifts either to the last syllable of the whole verb-clitic structure, or to the penultimate syllable. When the whole sequence ends in a consonant (except for the plural morph [-s]), stress shifts to the final syllable of the verb-clitic sequence. If it ends in a vowel, stress shifts to the penultimate syllable. These data support an analysis of enclitic-induced stress shift as a metrical optimizing strategy. In Formenteran Catalan, stress shifts in order to obtain a right-aligned moraic trochee (i.e. a left-headed, binary foot at the level of the mora). In second person plural imperatives, (2b), there is no stress shift if one enclitic is added because the last syllable of the verbal stem is already a heavy syllable and can therefore be parsed as a moraic trochee at the expense of right-alignment. Stress shift in Formenteran Catalan is illustrated in (2) with some examples.

1. There are some exceptions in Minorcan and certain subvarieties of Majorcan, in which stress shifts to the penultimate syllable of the whole sequence in some contexts due to output-output faithfulness (see Torres-Tamarit \& Pons-Moll 2019). 
(2) Stress shift in Formenteran Catalan
a. IMP.2SG IMP. $2 \mathrm{SG}=3$ SG.F.ACC
['kantə] [kən'tə $=$ lə]
'sing!' 'sing it.fem!'
b. IMP.2PL IMP.2PL=3SG.DAT
[kən'taw $]\left[\mathrm{k} ə n^{\prime}\right.$ taw $\left.=1 \mathrm{i}\right]$
'sing!' 'sing to him/her!'
c. INF. $\quad \mathrm{INF}=1 \mathrm{SG}=3$ SG.F.ACC
[kən'ta $] \quad\left[\mathrm{k} ə n t ə \mathrm{~s}={ }^{\prime} \mathrm{m} ə=\mathrm{l}\right.$ ]
'to sing' 'to sing it to me'

Central Catalan differs from these two dialects in not having stress shift in verbs with enclitics, as illustrated in (3).

(3) Absence of stress shift in Central Catalan
a. IMP.2SG IMP.2SG=3SG.F.ACC
['kantə] ['kantə $=$ lə]
'sing!' 'sing it.fem!'
b. IMP.2PL IMP.2PL=3SG.DAT
[kən'tew] [kən'tew =li]
'sing!' 'sing to him/her!'
c. INF. $\quad \mathrm{INF}=1 \mathrm{SG}=3 \mathrm{SG}$.F.ACC
[kən'ta $] \quad\left[\mathrm{kən}{ }^{\prime} \operatorname{tar}=\mathrm{m} ə=\mathrm{l}\right.$ ]
'to sing' 'to sing it to me'

\subsection{Stress in verb-clitic structures in Eivissan Catalan}

Eivissan Catalan (henceforth EC) stands apart from the rest of Balearic subdialects and Central Catalan. First of all, there is no stress shift in imperatives with enclitics. Second, stress shift is only found in penultimately-stressed second conjugation infinitives when followed by one or more pronominal enclitics in the subvariety of EC of interest here. This is not a coincidence: first and third conjugation infinitives in Catalan have final stress (e.g. [kən't-a] 'to sing', underlyingly /kant-a-r/; [ku'z-i] 'to sew', underlyingly /kuz-i-r/), with stress falling on the thematic vowel; but most second conjugation infinitives have penultimate stress (e.g. ['tem-ə] 'to fear', ['romp-rə] 'to break'). Very few second conjugation infinitives have final stress in Catalan (e.g. haver 'to have (aux.)', saber 'to know', poder 'to be able to', soler 'to usually do', valer 'to be worth', voler 'to want'). These second conjugation infinitives with final stress are not affected by stress shift. Third, stress is only shifted one syllable to the right, that is, to the last syllable of the verbal stem, and therefore never falls on any enclitic.

Before presenting the analysis of the stress pattern in infinitives with enclisis in $\mathrm{EC}$, we need an excursus into the morphology of second conjugation infini- 
tives. Most second conjugation infinitives in Catalan have two surface endings: $[-\partial(r)]$ and $[-\digamma \curvearrowright]$, with the final $[r]$ in $[-\partial(r)]$ being deleted word-finally if no enclitic follows due to a process of deletion of rhotics in word-final position in Catalan (e.g. [ku'nəf-ə], [kunə'f-ər =u]). According to Mascaró (1985), second conjugation infinitives have no thematic vowel. This is why stress falls on the verbal root in these second conjugation verbs. First and third conjugation verbs, as well as second conjugation verbs like saber 'to know', do have a thematic vowel, which is stressed in infinitives.

For EC, we assume that the infinitive morpheme has two allomorphs: /-r/ and /-ar/. If the last consonant of the verbal root is a sonorant (e.g. /m-, n-, r-/) or a sibilant (e.g. /s-, S-/), the allomorph /-ər/ is selected, which is pronounced [-ə] due to the process of word-final deletion of rhotics. If the last consonant of the verbal root is a stop (e.g. /p-, b-, t-, d-/) or the labiovelar glide (/w-/), the infinitive takes $/ \mathrm{r} /$, which is pronounced [-rə] due to the insertion of a final epenthetic schwa, required for syllabification, as assumed in Mascaró (1985) and subsequent work on Catalan morphophonology. Selecting /- $\mathrm{r} /$ is possible because stops (spirantized when voiced) can create a well-formed complex onset with /-r/ (e.g. [.pr], [.ßr] [.tr], [.ðr]), and the heterosyllabic contact [w.r] is not rising. A short list of second conjugation verbs in $\mathrm{EC}$ is given in (4).

(4) Second conjugation infinitives in Eivissan Catalan (adapted from Mascaró 1985: 112)

\begin{tabular}{|c|c|c|c|}
\hline inf. in $[-\partial]$ a & er sonorants or sibilants & inf. in $[-r \partial$ & ter stops an \\
\hline ['tem-ə] & 'to fear' & ['romp-гə] & 'to break' \\
\hline ['prem-ə] & 'to press' & ['bat-rə] & 'to shake' \\
\hline ['plan-ə] & 'to feel sorry' & ['регð-гә] & 'to lose' \\
\hline [әm'pən-ә] & 'to push' & ['bəw-rə] & 'to drink' \\
\hline ['vəns-ə] & 'to defeat' & ['kaw-rə] & 'to fall' \\
\hline ['tors-ə] & 'to twist' & ['rəß-гә] & 'to receive' \\
\hline ['kre $\left.\int-ә\right]$ & 'to grow' & & \\
\hline [ku'nəS-ə] & 'to know' & & \\
\hline 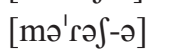 & 'to deserve' & & \\
\hline ['kor-ə] & 'to run' & & \\
\hline
\end{tabular}

There is still another type of verb within the second conjugation class whose verbal root ends in either $/ / \mathrm{n} /$ or $/ / 1 /$. These verbs would be expected to select the infinitive allomorph /-ər/, but take instead the allomorph / $\mathrm{r} /$, and avoid the heterosyllabic rising consonant cluster that would be created by the concatenation of the alveolar nasal or lateral with the rhotic through epenthesis of [-d-]. Some examples appear in (5). 
(5) Second conjugation infinitives in [-d-rə] in Eivissan Catalan (adapted from Mascaró 1985: 112)

[ən'sen-d-rə] 'to turn on'
['prən-d-rə] 'to take'
['vən-d-rə] 'to sell'
[di'sol-d-rə] 'to dissolve'
['mol-d-rə] 'to grind'
[rə'zəl-d-rə] 'to solve'

We will come back to these verbs in section 4 . As said before, stress shifts in EC when penultimately-stressed second conjugation infinitives are followed by pronominal enclitics. For now, we exemplify stress shift with those infinitives that end in $[-\partial(\varsigma)]$. No matter the number of clitics that follow the verb, stress in EC shifts only one syllable to the right, that is, to the last syllable of the verbal stem, leaving all enclitics unstressed. This is exemplified in (6). Note that the final rhotic in /-ər/ surfaces when an enclitic follows as it is not final anymore.

(6) Stress shift in penultimately-stressed second conjugation verbs in Eivissan Catalan
a. INF $\quad \mathrm{INF}=2 \mathrm{SG}$
[ku'nəf-ə] [kunə' $\int-\partial \mathrm{r}=\mathrm{t}$ ] $]$
'to know' 'to know you'
b. INF INF=1SG=3SG.F.ACC
[mə'r 2 -ə] [mərə' $-\partial \mathrm{r}=\mathrm{m} \partial=1 \partial]$
'to deserve' 'to deserve it myself'
c. INF INF=LOC
['kor-ə] [ku'r-ər $=\mathrm{i}]$
'to run' 'to run there'

In the next section we briefly introduce the representations and the constraint set used in Itô \& Mester (2009) to account for the prosodification of clitics. Building on their proposal, we will present an OT analysis of the EC data in section 3.3.

\section{Analysis}

\subsection{The prosodification of clitics}

The basic tenets of Prosodic Phonology (Selkirk 1981; Nespor \& Vogel 1986) are that phonological constituent structure is not necessarily isomorphic with syntactic constituent structure, and that phonological constituent structure is organized along a hierarchy of a finite set of universal prosodic categories referred to as the prosodic hierarchy (i.e. the syllable $<$ the foot $<$ the phonological word $<$ the phonological phrase $<$ the intonational phrase $<$ the utterance). A considerable 
body of work within OT has been devoted to the prosodification of function words since the pioneering work of Selkirk (1995). Building up on this work, Peperkamp (1997) established a typology of the prosodification of pronominal enclitics in ItaloRomance (see also Anderson 2011 for an overview). Later on, Itô \& Mester (2009), following Selkirk (1995), elaborated on the notion of recursive prosodic words in their analysis of function-lexical structures in German and English. In this paper we assume the representational principles and the constraint set of Itô \& Mester (2009). In Itô \& Mester (2009), four possible sites are identified for function words in a prosodic tree structure without any intervening prosodic categories between the prosodic word and the phonological phrase (as in Selkirk 1995 and Peperkamp 1997). These four sites are illustrated in (7). In (7a), the function word projects its own prosodic word and is therefore a prosodically independent form with respect to the lexical word. Both prosodic words are further parsed into a single phonological phrase. In (7b), the function word amalgamates with the prosodic word that contains the lexical host (i.e. an internal clitic in Selkirk's terminology). In (7c), the function word is adjoined to a recursive prosodic word that dominates the inner prosodic word containing the host (i.e. an affixal clitic in Selkirk's terminology). Finally, in (7d) the function word is directly attached to the phonological phrase (i.e. a free clitic in Selkirk's terminology). In what follows, $\omega$ stands for prosodic word and $\varphi$ for phonological phrase. ${ }^{2}$

(7) Four possible sites for function words in a prosodic tree structure (based on Itô \& Mester 2009: 150)
a. full- $\omega$ fnc
$\left((\text { lex })_{\omega}(\text { fnc })_{\omega}\right)_{\varphi}$
b. amalgamated fnc $\left((\text { lex } f n c)_{\omega}\right)_{\varphi}$
c. $\omega$-adjoined fnc $\left(\left((l e x)_{\omega} f n c\right)_{\omega}\right)_{\varphi}$
d. $\varphi$-attached fnc $\left((\text { lex })_{(0)} f n c\right)_{\varphi}$

\subsection{Optimal parsing of func-lex structures}

The specific parsing of func-lex structures depends on the language-particular ranking of a set of constraints on prosodic representation of different types: parsing constraints, interface constraints, size constraints, and tree form constraints. In Itô $\&$ Mester (2009), prosodic parsing is triggered by the satisfaction of a set of PARSEINTO-X constraints, where $\mathrm{X}$ is a variable that stands for all prosodic categories. For

2. In the early days of Prosodic Phonology, the Strict Layer Hypothesis (Selkirk 1984) advocated both full prosodic parsing and no recursivity. The theory was relaxed later on with the advent of Optimality Theory. 
our purposes it is enough to make use of just one parsing constraint: PARSE-INTO- $\omega$, defined in (8). PARSE-INTO- $\omega$ is violated by $\varphi$-attached function words $(7 \mathrm{~d})$, in which the function word is not parsed into any prosodic word.

(8) PARSE-INTO-w (Itô \& Mester 2009: 139)

Every element of the terminal string is parsed at the $\omega$-level.

Interface constraints are responsible for matching one edge (i.e. left or right) of certain syntactic constituents with one edge of a specific prosodic category. ${ }^{3}$ For the cases at hand, in which function words are pronominal enclitics, we just need one interface constraint: LEX-TO- $\omega(\mathrm{R})$, formulated in (9). ${ }^{4}$ This constraint penalizes the structure in $(7 \mathrm{~b})$; with proclisis this constraint would not be violated.

(9) LEX-TO- $\omega(\mathrm{R})$ (Itô \& Mester 2009: 142)

Every lexical word is right aligned with a prosodic word.

LEX-TO- $\omega(\mathrm{R})$ is violated by function words that amalgamate with their hosts at the right edge because the right edge of the lexical word does not match the right edge of any prosodic word.

Another crucial constraint is FoOTBINARITY, a size constraint defined in (10) that excludes full- $\omega$ function words, that is, prosodic words that contain subminimal, degenerate feet, on the proviso that function words are short enough. ${ }^{5}$

(10) FootBinarity (based on McCarthy \& Prince 1993: 58)

Every foot must be bimoraic or disyllabic.

Finally, a fourth constraint is needed to account for the full typology depicted in (7), the tree form constraint No-RECURSION in (11).

(11) No-RECURSION (Itô \& Mester 2009: 145)

An element is parsed only once into a given category. Assign one violation mark for each additional parse of an element into the same category.

We claim that pronominal enclitics in EC are $\omega$-adjoined function words (as in 7c) and therefore violate No-RECURSION. The optimal parsing of pronominal enclitics as $\omega$-adjoined function words depends on the constraint ranking illustrated in the tableau in (12). Candidate (12d), with a full- $\omega$ enclitic, violates FoOTBINARITY because the clitic projects its own prosodic word and is therefore parsed by a

3. In constraint-based theories of the phonology-syntax interface it is consensual that only lexical syntactic categories can be referred to by interface constraints.

4. A more recent theory of the phonology-syntax interface is Match Theory (proposed in Selkirk 2009, 2011; see also Elfner 2011 and Itô \& Mester 2013). Match Theory requires units of syntactic structure to have corresponding units in the prosodic structure. LEX-TO- $\omega(\mathrm{R})$ could be reformulated as MATCH(Lex, PWd), in which the latter does not make reference to edges.

5. This is only true for monomoraic function words. 
subminimal foot. Candidate (12c) exemplifies a case of an amalgamated enclitic, which is ruled out because it fatally violates the interface constraint LEX-TO- $\omega(\mathrm{R})$. Candidate (12b), with a $\varphi$-attached enclitic, violates the parsing constraint PARSEINTO- $\omega$ because the enclitic is not parsed by any prosodic word and it simply skips this level to directly attach to the phonological phrase. Finally, the winning candidate is candidate (12a), with a $\omega$-adjoined enclitic, which violates the constraint No-RECURSION. This constraint is dominated by all the other constraints mentioned so far.

(12) Constraint ranking for $\omega$-adjoined enclitics in Eivissan Catalan

\begin{tabular}{|c|c|c|c|c|}
\hline$l e x f n c$ & FTBIN & LEX-TO- $\omega(\mathrm{R})$ & PARSE-INTO- $\omega$ & NO-REC \\
\hline a. $\left(\left((l e x)_{\omega} f n c\right)_{\omega}\right)_{\varphi}$ & & & & $*$ \\
\hline b. $\left((l e x)_{\omega} f n c\right)_{\varphi}$ & & & $* \mathrm{~W}$ & $\mathrm{~L}$ \\
\hline c. $\left((l e x f n c)_{\omega}\right)_{\varphi}$ & & $* \mathrm{~W}$ & & $\mathrm{~L}$ \\
\hline d. $\left((l e x)_{\omega}(f n c)_{\omega}\right)_{\varphi}$ & $* \mathrm{~W}$ & & & $\mathrm{~L}$ \\
\hline
\end{tabular}

In the next section we give evidence for recursive prosodic words in verb-clitic structures in EC and discuss their prosodification.

\subsection{Recursive prosodic words in Eivissan Catalan: prosodic domains}

Leaving aside Formenteran, Majorcan and Minorcan Catalan, whose pronominal enclitics are necessarily amalgamated function words due to the observed systematic stress shift, we argue that, in EC, pronominal enclitics are $\omega$-adjoined function words, derived by the constraint ranking in (12). In such a representation, the lexical category, the verb, coincides with the boundaries of a minimal prosodic word $\omega_{\min }$, which is further dominated by a maximal prosodic word $\omega_{\max }$ that integrates the enclitic(s), as illustrated in (13), parallel to (7c). ${ }^{6}$

(13) Minimal and maximal prosodic words in verb-clitic structures in Eivissan Catalan $\left(\left((V)_{\omega \min } c l\right)_{\omega \max }\right)_{\varphi}$

The structure in (12b), in which the clitic directly attaches to the phonological phrase, must be excluded because postverbal clitics affect the location of stress; clitics cannot lie outside the domain of stress assignment, which is the prosodic

6. It is enough for our purposes to simply distinguish between minimal and maximal words. See Itô \& Mester (2007, 2009, 2012, 2013), van der Hulst (2010), Selkirk (2011), Elfner (2015), MartínezParicio (2012), Martínez-Paricio \& Kager (2015), Bennett (2018), among others, for recursivity in metrical and prosodic phonology and the necessity of labels based on dominance relations in recursive prosodic structures. 
word. The structure in (12c), in which the clitic amalgamates prosodically with the verbal host must also be discarded because postverbal clitics never receive stress in EC. Finally, the structure in (12d), in which the clitic is parsed into its own prosodic word, is also inadequate for EC for the same reason: clitics never receive stress. ${ }^{7}$

We should now ask what kind of evidence is available that gives support to the representation in (13) with recursion as adjunction. Independent evidence comes from segmental phonology. In Catalan (except for Valencian Catalan), rhotics delete in word-final position (see Bonet \& Lloret 1998). ${ }^{8}$ Some morphophonological alternations are illustrated in (14) for EC.

(14) Word-final deletion of rhotics in Eivissan Catalan

$\begin{array}{lllll}\text { [fus'te] } & \text { 'carpenter' } & c f . & \text { [fustə'riə] } & \text { 'carpentry' } \\ \text { ['ma] } & \text { 'sea' } & c f . & \text { [məri'ne] } & \text { 'sailor' } \\ \text { [rə'mo] 'noise' } & c f . & \text { [rəmu'rətə] } & \text { 'small noise' }\end{array}$

In addition, consonantal clusters formed by a nasal or a lateral plus a homorganic stop undergo deletion of the stop in word-final position (except for Valencian and Majorcan Catalan). Some morphophonological alternations are illustrated in (15) for EC.

(15) Word-final cluster simplification in Eivissan Catalan

$\begin{array}{lllll}\text { ['san] } & \text { 'saint' } & c f . & \text { [səntə'ðat] } & \text { 'holiness' } \\ \text { ['ven] } & \text { 'wind' } & c f . & \text { [vən'taðə] } & \text { 'strong wind' } \\ \text { ['fon] } & \text { 'wellspring' } & c f . & \text { [fun'tətə] } & \text { 'small wellspring' }\end{array}$

Both deletion of rhotics and cluster simplification apply in word-final position, also when they are followed by a vowel-initial word, as seen in (16).

7. Peperkamp (1997) also proposes a recursive prosodic word as an explanation for enclitic-induced stress shift in Neapolitan. In Neapolitan, imperatives followed by one enclitic have no stress shift, but when two enclitics follow, stress falls on the first enclitic and the verb surfaces with secondary stress (e.g. porta $=t_{i l}=l$ la). This is not what we find in $\mathrm{EC}$, in which only one stress surfaces in infinitives followed by one or more enclitics. Two different analyses can be assumed for infinitives followed by two enclitics in EC: (i) every enclitic is attached independently to a recursive prosodic word, or (ii) all enclitics are adjoined to the same maximal prosodic word. We will assume that the domain for stress assignment is the minimal prosodic word. If this is assumed, the constraint responsible for determining the minimal prosodic word as the domain for stress assignment would be enough to exclude building a foot on top of the enclitics. Then, all clitics can be simply adjoined to the same maximal prosodic word, minimizing the number of violations of No-RECURSION. If the domain for stress assignment were any prosodic word, then another constraint should exclude the possibility of parsing enclitics into a foot. This constraint could be a HEAD-TO-LEX constraint "requiring heads of prosodic categories to be contained in lexical (not functional) material (Itô \& Mester 2009: 187)".

8. In nouns and adjectives, word-final rhotic deletion applies only after a stressed vowel. In Eivissan and Formenteran Catalan rhotics also delete after unstressed vowels in verbs. 
(16) Application of both deletion processes before vowel-initial words in Eivissan Catalan

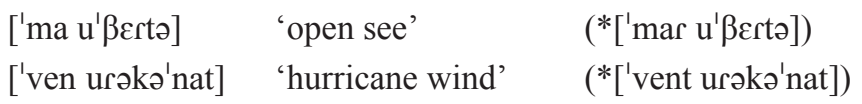

In verb-clitic structures, however, both deletion processes are blocked, as shown in (17).

(17) Blocking of deletion processes in verb-clitic structures in Eivissan Catalan

$$
\begin{array}{lll}
{[\text { kən'tar }=\mathrm{m} ə]} & \text { 'to sing to me' } & \left({ }^{*}\left[\mathrm{k} ə n^{\prime} \text { ta }=\text { mə] }\right)\right. \\
{[\text { kum'prant }=\mathrm{i}]} & \text { 'buying there' } & \left({ }^{*}[\text { kum'pran }=\mathrm{i}]\right)
\end{array}
$$

From the data in (16) it is clear that the prosodic domain of rhotic deletion and cluster simplification is not the phonological phrase, but the maximal word (e.g. $\left.\left((' m a)_{\omega \max }\left(u^{\prime} \beta \varepsilon r t \partial\right)_{\omega \max }\right)_{\varphi}\right)$. If enclitics attached directly to the phonological phrase, one would expect the two deletion processes to apply in verb-clitic structures, contrary to facts $\left(\mathrm{e} . \mathrm{g} *\left[\mathrm{k} ə n^{\prime} \mathrm{ta}=\mathrm{m} ə\right]\right.$, with a structure $\left(\left(\mathrm{kən} \mathrm{n}^{\prime} \mathrm{ta}\right)_{\omega}=\mathrm{m} ə\right)_{\varphi}$, instead of $\left.\left[\mathrm{k} \mathrm{n}^{\prime} \mathrm{tar}=\mathrm{m} ə\right]\right)$. If a recursive structure is assumed for verb-clitic structures, the rhotic and the consonantal cluster are not final at the level of the maximal word, only at the level of the minimal prosodic word, and hence deletion is not expected. ${ }^{9}$

If the prosodic domain for stress assignment in $\mathrm{EC}$ is the minimal prosodic word, and the domain for the deletion processes is the maximal prosodic word, all the observed facts follow, including the locality effect of stress shift in verb-clitic structures, which is circumscribed to move one syllable to the right, that is, to the last syllable of the verbal stem, but not further. In verb-clitic structures, the verb is prosodified on its own minimal prosodic word. In those second conjugation verbs ending in $/-\partial r /$, the process of deletion of rhotics is blocked because the rhotic is not final within the maximal prosodic word, the one that contains the enclitic. The fact that deletion does not apply makes the last syllable of the verbal stem a heavy syllable, and therefore stress shifts one syllable to the right to conform with the unmarked stress pattern of Catalan: a right-aligned moraic trochee, as illustrated in (18). Parentheses mark foot boundaries and square brackets prosodic word boundaries. In isolation, second conjugation verbs have penultimate stress because, as opposed to first and third conjugation verbs, they have no thematic vowel, which is always stressed.

9. One could assume that the prosodic domain of both processes of deletion is the clitic group, a distinct prosodic category. However, such an analysis would need to posit such a category for every non-cliticized word, in which the deletion processes also apply $\left(\right.$ e.g. $\left.\left(\left((' \mathrm{ma})_{\omega}\right)_{\mathrm{ClGr}}\left(\left(\mathrm{u}^{\prime} \beta \varepsilon \mathrm{rt} ə\right)_{\omega}\right)_{\mathrm{ClGr}}\right)_{\varphi}\right)$. These forms face the problem of "too much structure". See Itô \& Mester (2009) for more arguments against the clitic group. 
(18) Stress shift in Eivissan Catalan

$$
\begin{aligned}
& \text { V } \\
& \mathrm{V}=\mathrm{cl} \\
& {\left[\mathrm{ku}\left({ }^{1} \mathrm{n} ə \int-\partial\right)\right]_{\omega \min , \max }} \\
& {\left[\left[\operatorname{kun}\left({ }^{\prime} \int-\partial r\right)\right]_{\omega \min }=\mathrm{t} \partial\right]_{\omega \max }}
\end{aligned}
$$

The constraints responsible for stress assignment in EC are the size constraint FOOTBINARITY- $\mu$, which disfavors feet that are not binary under a moraic analysis; the foot form constraint TROCHEE, which disfavors feet whose head is not left-aligned, and which dominates IAMB; and a specific version of the alignment constraint All-FeEt-Right, that is, All-FeEt-Right(wmin), which needs to refer to the right edge of minimal prosodic words. In the tableau in (19) we illustrate stress shift in second conjugation verbs followed by one enclitic. The last syllable of the verbal stem being heavy, a foot can be built at the right edge of the minimal prosodic word without incurring a violation of ALL-FEET-Right( $\omega$ min). For the

\begin{tabular}{|c|c|c|c|c|c|}
\hline $\operatorname{kun} \partial-\{r>\partial r\}=$ tə & 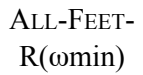 & TROCHEE & FоOтBIN- $\mu$ & $\begin{array}{l}\text { ALL-FEET- } \\
\text { L( } \omega \text { min })\end{array}$ & IAMB \\
\hline a. $\left[\left[\operatorname{kun} ə\left(1 \int \partial r\right)\right]_{\omega \min } \text { tə] }\right]_{\omega \max }$ & & & & $* *$ & $*$ \\
\hline b. $\left[\left[\mathrm{ku}\left(\mathrm{n} \partial^{\prime} \int \partial r\right)\right]_{\omega \min } \mathrm{t}\right]_{\omega \max }$ & & $* \mathrm{~W}$ & $* \mathrm{~W}$ & $* \mathrm{~L}$ & $\mathrm{~L}$ \\
\hline c. $\left[\left[\mathrm{ku}(\mathrm{\prime} n \ni) \int \partial r\right]_{\omega \min } \text { tə] }\right]_{\omega \max }$ & $* \mathrm{~W}$ & & $* \mathrm{~W}$ & $* \mathrm{~L}$ & $\mathrm{~L}$ \\
\hline
\end{tabular}
selection of the infinitive allomorph /-or/ over/-r/, see section 4 .

(19) Stress shift in a second conjugation verb followed by one enclitic in Eivissan Catalan

In EC, there is simply no stress shift in first and third conjugation verbs with enclisis because these infinitives always have final stress, and therefore metrical optimization is satisfied vacuously, as illustrated in (20). In this example, the isolated infinitive ends up surfacing with a degenerate foot due to the process of word-final deletion of rhotics (a case of phonological opacity between segmental deletion and stress assignment). In verb-clitic structures, as already seen, the rhotic does not delete and the foot is binary under a moraic analysis. There is no stress shift because stress is already final in the isolated infinitive.

(20) No stress shift in first conjugation verbs in Eivissan Catalan

$$
\begin{aligned}
& \text { V } \\
& \mathrm{V}=\mathrm{cl} \\
& {[\mathrm{kən}(\mathrm{t}-\mathrm{t}-\mathrm{a})]_{\omega \min , \max }} \\
& {\left[[\mathrm{kən}(\mathrm{t} \mathrm{t}-\mathrm{a} \Gamma)]_{\omega \min }=\mathrm{mə}=\mathrm{l} ə\right]_{\omega \max }}
\end{aligned}
$$

In Formenteran Catalan, however, clitics are amalgamated within the same prosodic word that contains the host, and therefore there is only one prosodic word in structures with enclisis. This prosodic word is both minimal and maximal, and therefore stress can shift all the way to the right as shown in (21) to optimize the 
metrical structure and, in the presence of two enclitics with the shape CVCV, a metrical foot is built on top of them. ${ }^{10}$

(21) Stress shift in first conjugation verbs in Formenteran Catalan

$$
\begin{aligned}
& \mathrm{V} \quad \mathrm{V}=\mathrm{cl} \\
& {[\mathrm{kən}(\mathrm{l} \mathrm{t}-\mathrm{a})]_{\omega \min , \max } \quad[\mathrm{kənt}-\partial \mathrm{r}=(\text { 'mə }=\mathrm{l})]_{\omega \min , \max }}
\end{aligned}
$$

In the next section we describe and analyze the two cases of allomorphy found in infinitive-clitic structures in EC.

\section{Allomorphy in infinitive-clitic structures in Eivissan Catalan}

In this section, we focus on the phonological alternations found between infinitives in isolation and infinitives followed by pronominal enclitics in both Eivissan (EC) and Formenteran Catalan (FC). As will be seen, in EC the infinitive can surface with the ending [-ər] when followed by enclitics, even though the form in isolation has [-rə]. In FC, those verbs ending in [-rə] in isolation surface systematically with [-rər], that is, with a double realization of the infinitive morph

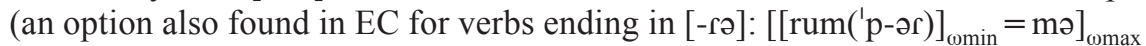
and $\left[[\operatorname{rum}(\operatorname{p}-\mathrm{r} \partial r)]_{\omega \min }=\mathrm{m} ə\right]_{\omega \max }$; therefore, there is variation in EC). ${ }^{11}$ Before discussing the data in more detail, let us first present the analysis of allomorph selection of the infinitive morph in isolated forms. As mentioned in section 2, we assume that EC, as well as FC, has two lexically ordered infinitive morphs: /-r/ and $/-\partial r /(\{r>\partial r\})$. We claim that it is the phonology that governs the selection of the allomorph since it depends on the last consonant of the verbal root. The constraint set that regulates allomorph selection appears in (22).

10. For EC an analysis in terms of amalgamated function words is also possible, as long as an asymmetric output-output constraint is added that requires sequences with two enclitics to be stressed like sequences with one enclitic, which acts as the base. The form with two clitics $\left[\operatorname{mər} \partial\left(\int-\partial r\right)=\mathrm{m} \partial=1 \partial\right]_{\omega}$ has stress on the last syllable of the verb because it is based on $\left[\operatorname{mor}\left({ }^{\prime}-\partial r\right)=\right.$ mə], with the less severe violation of ALL-FEET-R; forms with one vocalic clitic, like $(6 \mathrm{c}),\left[\mathrm{ku}\left({ }^{\prime} \mathrm{r}-\partial \mathrm{r}=\mathrm{i}\right)\right]$ 'to run there', would have a perfectly right-aligned moraic trochee in this analysis. In our recursivity-based analysis, asymmetric output-output constraints are unnecessary. Forms with one vocalic clitic, however, do pose a challenge to the recursivitybased analysis. Resyllabification of the infinitive morph as the onset of the vocalic clitic triggers a violation of both LEX-TO- $\omega(\mathrm{R})$ and FTBIN: $\left[\left[\mathrm{ku}\left({ }^{\prime} \mathrm{r}-\partial\right)\right]_{\omega \min } \mathrm{f}=\mathrm{i}\right]_{\omega \max }$. Maintaining such a form as the optimal candidate requires another type of output-output constraint, in the line of the model Optimal Paradigms (McCarthy 2005). In this case the paradigm would consist of the infinitive plus all the possible clitics and an OP-IDENT(stress) constraint would favor paradigms with uniform stress. Since most of the clitics start with a consonant they would drag infinitives with a vowel-initial clitic into their stress pattern. We thank an anonymous reviewer for drawing our attention to the issues posed by vowel-initial clitics.

11. Our impression is that variation between [-ər] and [-гər] in EC is a case of free variation, but further investigation is needed to elucidate whether this variation is dependent on extralinguistic factors. 
(22) Constraint set regulating the allomorph selection of the infinitive morpheme

a. CODA-Condition (based on McCarthy 2008: 277)

Assign one violation mark for every coda that licenses a consonantal place feature (it prohibits all coda consonants except for homorganic ones).

b. Syllable-Contact (McCarthy 2008: 229)

Assign one violation mark for every heterosyllabic consonant cluster with rising sonority.

c. Priority (Mascaró 2007: 726)

Respect lexical priority (ordering) of allomorphs.

d. DEP-C

Assign one violation mark for every consonant in the output that does not have a correspondent in the input.

The effect of each constraint is shown in the following tableaux. First consider an infinitive in which the last consonant of the root is a sibilant (23). In such a case, syllabifying the sibilant in coda position implies a fatal violation of CoDACONDition (candidates 23b and 23c) and of Syllable-CONTACT if no epenthetic consonant intervenes (candidate 23b). The winner, which has undergone final rhotic deletion through constraints not included in the tableau, surfaces with the less preferred allomorph, violating PRIORITY, and therefore satisfies the two undominated constraints, CODA-CONDITION and SyLLABLE-CONTACT.

(23) Tableau for $/ \operatorname{kun} ə \int-\{r>$ or $\} /$

\begin{tabular}{|c|c|c|c|c|}
\hline $\operatorname{kun} \partial \int-\{r>$ or $\}$ & CODA-COND & SylL-CONT & PRIORITY & DEP-C \\
\hline a. ku.'nə.Јə & & & $*$ & \\
\hline b. ku.'nə⿻.rə & $* \mathrm{~W}$ & $* \mathrm{~W}$ & $\mathrm{~L}$ & \\
\hline c. ku.'nəృ.ðrə & $* \mathrm{~W}$ & & $\mathrm{~L}$ & $* \mathrm{~W}$ \\
\hline
\end{tabular}

If the last consonant of the verbal root can be syllabified as a complex onset together with the rhotic, the preferred allomorph / $\mathrm{f} /$ is selected, as shown in (24). Candidate (24a) harmonically bounds all other candidates: there is no reason to select the less preferred allomorph /or/, and consonant epenthesis introduces a gratuitous violation of DEP-C. We omit the constraint DEP-V, which is also violated by the winning candidate with a final epenthetic schwa. 
(24) Tableau for /romp- $\{\mathrm{r}>$ ər $\} /$

\begin{tabular}{|c|c|c|c|c|}
\hline romp- $\{r>\partial r\}$ & CODA-COND & SYLL-CONT & PRIORITY & DEP-C \\
\hline a. 'rom.prə & & & & \\
\hline b. 'rom.pə & & & $* \mathrm{~W}$ & \\
\hline c. 'ron.drə & & & & $* \mathrm{~W}$ \\
\hline
\end{tabular}

A similar situation is observed for verbs whose last consonant is /-w/. In such cases, the labiovelar glide can be syllabified in coda position without incurring a violation of SyLLABLE-CONTACT. ${ }^{12}$

(25) Tableau for /trew- $\{\mathrm{r}>$ or $\} /$

\begin{tabular}{|c|c|c|c|c|}
\hline trew- $\{r>$ ər $\}$ & CODA-COND & SYLL-CONT & PRIORITY & DEP-C \\
\hline a. 'trew.rə & & & & \\
\hline b. 'tre.wə & & & $* \mathrm{~W}$ & \\
\hline c. 'trew.ðrə & & & & $* \mathrm{~W}$ \\
\hline
\end{tabular}

Finally, verbs ending in /-n/ or /-1/ can take the preferred allomorph / $/$ / because by epenthesizing [-d-] forms like (26a) do not violate any markedness constraints. It is crucial that PRIORITY outranks DEP-C. ${ }^{13}$

(26) Tableau for /onsen- $\{\mathrm{r}>$ ər $\} /$

\begin{tabular}{|c|c|c|c|c|}
\hline ənsen- $\{\mathrm{r}>$ ər $\}$ & CODA-COND & SYll-CONT & PRIORITY & DEP-C \\
\hline a. ən.' sen.drə & & & & $*$ \\
\hline b. ən.' se.nə & & & $* \mathrm{~W}$ & $\mathrm{~L}$ \\
\hline c. ən.' sen.rə & & $* \mathrm{~W}$ & & $\mathrm{~L}$ \\
\hline
\end{tabular}

12. We assume a version of CODA-CONDITION that affects segments in the coda with the feature [+consonant]. For this reason the winner in $(25 \mathrm{a})$, with a glide in coda position, does not violate the constraint.

13. We exclude from the tableau in (26) a candidate like [ən.'sen.rə], in which the flap maps onto a trill (an output found in some varieties of Catalan). If we assume that trills are as sonorous as stops (Bonet \& Mascaró 1997), this candidate would not violate SyLLABLE-ConTACt, but it would be ruled out by a higher-ranked identity constraint against changing the feature value that distinguishes taps from trills. Pons-Moll (2011) assumes that the trill is more sonorous than nasals but less sonorous than flaps. A candidate like [ən.'sen.rə], with a trill, would still violate Syllable-ConTACT, but to a lesser degree than [ən.'sen.rə], with a flap. 
Turning now to infinitives with enclitics, second conjugation verbs that end in $[-\partial(\mathrm{r})]$ remain unaltered with respect to the infinitive allomorph selected both in EC and in FC. A few examples are illustrated in (27). The only difference has to do with stress placement due to the presence of a recursive prosodic word in EC, but not in FC.

(27) Stress shift in verbs ending in $[-\partial(\varsigma)]$

a. EC

$$
\begin{aligned}
& \text { inf. } \quad\left[\operatorname{mo}\left(' r \partial \int-\partial\right)\right]_{\omega \min , \max } \\
& \text { inf. }+1 \mathrm{Cl} \quad\left[[\operatorname{mər} \partial(\mathrm{I}-\partial r)]_{\omega \min }=\operatorname{mə}\right]_{\omega \max } \\
& \text { inf. }+2 \mathrm{Cl}\left[[\operatorname{mor} \partial(\mid \mathrm{f}-\partial r)]_{\omega \min }=\mathrm{m} \partial=1 \partial\right]_{\omega \max }
\end{aligned}
$$

b. FC

$$
\begin{aligned}
& \text { inf. } \quad\left[\operatorname{mə}\left({ }^{\prime} r \partial \int-ə\right)\right]_{\omega \min , \max } \\
& \text { inf. }+1 \mathrm{Cl}\left[\operatorname{mor} \partial\left({ }^{\prime}-\partial r\right)=\mathrm{m}\right]_{\omega \min , \max } \\
& \text { inf. }+2 \mathrm{Cl} \quad\left[\operatorname{mər} \partial \int-\partial r=\left({ }^{\prime} \mathrm{m} ə=l ə\right)\right]_{\omega \min , \max }
\end{aligned}
$$

Interestingly, second conjugation verbs ending in [-rə] and [-d-rə] do not surface as such under enclisis. In EC, the ending is instead [-ər], following the pattern of forms like $\left[[\operatorname{mor}(\mid \mathrm{S}-\partial r)]_{\omega \min }=\mathrm{m} \partial\right]_{\omega \max }$, and in $\mathrm{FC}$, the infinitive morph is expressed twice (i.e. [-гər]). ${ }^{14}$ Some examples appear in (28).

(28) Allomorphy in verbs ending in [-гə]

a. $\mathrm{EC}$

$$
\begin{aligned}
& \text { inf. } \quad[(\text { 'rom }) \mathrm{p}-\mathrm{r} \partial)]_{\omega \min , \max }
\end{aligned}
$$

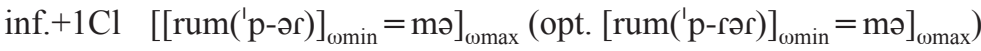

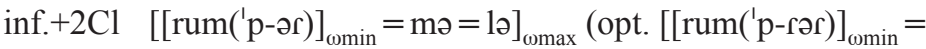

$$
\begin{aligned}
& \left.\mathrm{mə}=l ə]_{\omega \max }\right)
\end{aligned}
$$

b. FC

$$
\begin{array}{ll}
\text { inf. } & {[(\text { 'rom }) \text { p-rə) }]_{\omega \min , \max }} \\
\text { inf. }+1 \mathrm{Cl} & [\text { rum('p-rər })=\mathrm{m} ə]_{\omega \min , \max } \\
\text { inf.+2Cl } & {\left[\text { rump-rər }=(\text { 'mə=lə) }]_{\omega \min , \max }\right.}
\end{array}
$$

14. In Majorcan Catalan, the epenthetic [-d-] in verbs whose last consonant ends in /-n, - $1 /$ is maintained as in FC, and the infinitive morph is repeated, surfacing with total assimilation to the following consonant (e.g. [ənsən-d-rəl=('lo)] 'to turn it.m on'). However, we have observed that it is also possible to take the thematic vowel of third conjugation verbs in the presence of enclitics (e. g. [əprən-i-1=('lo)] 'to learn it.M'). This possibility is also attested in imperatives with enclitics (e.g. [əргə('n-i=1)] 'learn it.M!') (see Bonet \& Torres-Tamarit 2011 for more details on imperatives). Future research on this topic in Majorcan and Minorcan Catalan is still necessary to fully understand allomorphy in infinitives followed by enclitics. 
(29) Allomorphy in verbs ending in [-d-rə]

a. EC

$$
\begin{aligned}
& \text { inf. [ən('sen)-d-rə] }]_{\omega \min , \max } \\
& \text { inf. }+1 \mathrm{Cl} \quad\left[[\text { ənsə('n-ər) }]_{\omega \min }=\operatorname{mə}\right]_{\omega \max }
\end{aligned}
$$

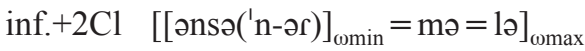

b. FC

$$
\begin{aligned}
& \text { inf. } \quad[\text { ən('sen)-d-rə] }]_{\omega \min , \max } \\
& \text { inf. }+1 \mathrm{Cl} \quad[\text { วnsən-('d-rər) }=\mathrm{m}]_{\omega \min , \max } \\
& \text { inf. }+2 \mathrm{Cl} \quad\left[\text { ənsən-d-rə厂 }=\left({ }^{\prime} \mathrm{mə}=1 \partial\right)\right]_{\omega \min , \max }
\end{aligned}
$$

Furthermore, in EC, second conjugation verbs that end in /-w/ can present another peculiarity, root allomorphy. In these verbs, the ending [-rə] of the infinitive is not only replaced by [-ər], but the verbal root, instead of ending in the expected $/-\mathrm{w} /$, ends in /-g/; this is the root allomorph used in the subjunctive mood, and also in gerunds and participles (i.e. mou ['mow] '(s)he moves' cf. mogui ['moy-i] '(s)he moves.SUBJ', moguent [mu'yen] 'moving', mogut [mu' yut] 'moved'). ${ }^{15}$ In FC, as expected, the infinitive ending is just [-rər]. ${ }^{16}$

(30) Root allomorphy in verbs whose root ends in /-w/

a. EC

$$
\begin{array}{ll}
\text { inf. } & {\left[(\text { 'məw)-rə] }]_{\omega \min , \max }\right.} \\
\text { inf. }+1 \mathrm{Cl} & {\left[\left[\mathrm{mu}\left({ }^{\prime} \mathrm{\gamma}-\partial r\right)\right]_{\omega \min }=\mathrm{m} \partial\right]_{\omega \max }} \\
\text { inf. }+2 \mathrm{Cl} & {\left[\left[\mathrm{mu}\left({ }^{\prime} \mathrm{\gamma}-\partial r\right)\right]_{\omega \min }=\mathrm{m} \partial=l \partial\right]_{\omega \max }}
\end{array}
$$

b. FC

$$
\begin{aligned}
& \text { inf. } \quad[(' \mathrm{~m} \supset \mathrm{w})-\mathrm{r} \partial]_{\omega \min , \max } \\
& \text { inf. }+1 \mathrm{Cl} \quad\left[\operatorname{muw}\left({ }^{\prime}-\mathrm{r} \partial \mathrm{r}\right)=\mathrm{m} \partial\right]_{\omega \max } \\
& \text { inf. }+2 \mathrm{Cl} \quad\left[\text { muw-rər }=\left({ }^{\prime} \mathrm{m} ə=l ə\right)\right]_{\omega \min , \max }
\end{aligned}
$$

To sum up, in both EC and FC the variation found in isolated infinitives (e.g. [mə'rəf-ə] vs. ['romp-rə]) is neutralized under enclisis: all infinitives end in [-ər] (optionally in [-rər]) in EC, and in [-rər] in FC. On top of this, EC also exhibits a case of root allomorphy in verbs whose root ends in /-w/.

As shown below, we analyze the allomorphy of the infinitive morph under enclisis as triggered by the same constraints responsible for stress assignment in Catalan, with no need to make use of new constraints. Furthermore, we propose

15. Some examples have been obtained from spontaneous speech in colloquial environments where native speakers of EC were not aware of the fact that the linguist was scrutinizing their speech:

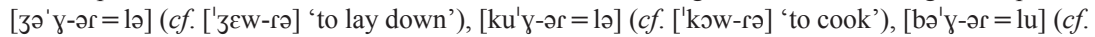
['bəw-rə] 'to drink'), [trə'y-ər= lus] ( $c f$. ['trew-rə] 'to remove').

16. Root allomorphy is also attested in younger speakers of FC. 
that root allomorphy is due to a markedness constraint that prohibits $/ \mathrm{w} /$ in the onset position of stressed syllables (this prohibition is in fact observed in all verbal forms in Catalan, as will be shown).

We start by recalling the analysis of stress shift in second conjugation verbs ending in [-ər], which was shown in (19), repeated below in (31) for convenience.

(31) Stress shift in a second conjugation verb followed by one enclitic in Eivissan Catalan

\begin{tabular}{|c|c|c|c|c|c|}
\hline $\operatorname{kun} ə \int-\{r>$ or $\}=$ tə & 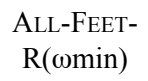 & TROCHEE & FTBIN- $\mu$ & $\begin{array}{l}\text { ALL-FEET- } \\
\text { L( } \omega \text { min })\end{array}$ & IAMB \\
\hline a. $\left[[\mathrm{kun} \partial(\mathrm{f} \partial r)]_{\omega \min } \mathrm{t} \partial\right]_{\omega \max }$ & & & & $* *$ & * \\
\hline b. $\left[\left[\mathrm{ku}\left(\mathrm{n}{ }^{\prime} \int \partial r\right)\right]_{\omega \min }^{\mathrm{t}}\right]_{\omega \max }$ & & $* \mathrm{~W}$ & $* \mathrm{~W}$ & $* \mathrm{~L}$ & $\mathrm{~L}$ \\
\hline c. $\left[\left[\mathrm{ku}\left(\text { 'nə) } \int \partial r\right]_{\omega \min }{ }^{\mathrm{t} ə}\right]_{\omega \max }\right.$ & $* \mathrm{~W}$ & & $* \mathrm{~W}$ & $* \mathrm{~L}$ & $\mathrm{~L}$ \\
\hline
\end{tabular}

The constraint PRIORITY, defined in (22c), becomes relevant in infinitives ending in [-rə] in isolation, as well as the constraint *AFFIXREPETITION, defined in (32), which disfavors multiple output correspondents of a single morpheme. ${ }^{17}$

\section{(32) *AFFIXREPETITION}

Assign one violation mark for every affix that has more than one corresponding morph. (See Ortmann 1999)

When stress shifts to the last syllable of the verbal stem in order to satisfy ALLFEET-R(wmin), there are only two possibilities to also satisfy FOOTBINARITY- $\mu$, as illustrated in (33). One possibility is to express the infinitive morpheme twice with the same allomorph and medial schwa epenthesis, (candidate $33 \mathrm{~d}$ ). ${ }^{18}$ This is the solution in FC. Another possibility is to select the less preferred infinitive allomorph /or/, as in (33a); the last segment of the verbal form of this candidate can be syllabified as a coda and therefore makes the last syllable of the verbal stem heavy. In this analysis, the allomorphy of the infinitive morpheme in verb-clitic structures is triggered by the constraints responsible for stress shift, ALL-FEET-R( $\omega$ min) and FoOtBINARITY- $\mu$, violated by candidates (33b) and (33c), respectively. In FC, PRIORITY must be ranked above *AFFIXREPETITION to model the optimality of candidate (33d). Each allomorph of the infinitive morpheme is identified with a subindex for clarity.

17. We could alternatively interpret the doubling of the infinitive morph as a case of consonant copy epenthesis (Kawahara 2007).

18. A homophonous candidate would be one in which, instead of expressing the first allomorph twice, the two allomorphs of the same morpheme are both expressed. This candidate would violate PRIORITY in addition to *AFFIXREPETITION and therefore would be harmonically bounded by the candidate in which the same allomorph, the least marked, has been repeated. 
(33) Tableau for /romp- $\{\mathrm{r}>$ ər $\}=$ lə/ in Eivissan Catalan

\begin{tabular}{|c|c|c|c|c|}
\hline romp- $\left\{\mathrm{r}_{1}>\partial \mathrm{r}_{2}\right\}=l \partial$ & *AFFREP & 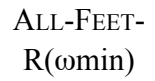 & FTBIN- $\mu$ & PRIOR \\
\hline a. $\left[\left[\operatorname{rum}\left(1 \mathrm{p}-\partial r_{2}\right)\right]_{\omega \min }=l ə\right]_{\omega \max }$ & & & & $*$ \\
\hline b. $\left[\left[\operatorname{rum}\left(\mid p-r_{1} \partial\right)\right]_{\omega \min }=l ə\right]_{\omega \max }$ & & & $* \mathrm{~W}$ & $\mathrm{~L}$ \\
\hline c. $\left[\left[(\text { 'rom }) p-\varsigma_{1} ə\right]_{\omega \min }=l ə\right]_{\omega \max }$ & & $* \mathrm{~W}$ & & $\mathrm{~L}$ \\
\hline d. $\left[\left[\operatorname{rum}\left(\operatorname{p}-r_{1} \partial r_{1}\right)\right]_{\omega \min }=l \partial\right]_{\omega \max }$ & $* \mathrm{~W}$ & & & $\mathrm{~L}$ \\
\hline
\end{tabular}

The same analysis applies for infinitives ending in [-d-rə] in isolation, in which the epenthetic [-d-] does not surface in forms with enclitics and the less preferred allomorph /or/ is also selected.

As mentioned above, second conjugation verbs whose root ends in the labiovelar glide /-w/ do not only show allomorphy of the infinitive morph as illustrated in (33), but also root allomorphy. In these verbs, the infinitive takes the verbal root found in the subjunctive and the other impersonal forms, gerund and participle, which end in /-g/ (moure ['mowrə] '(s)he moves' but moguer-la [mu'yər = lə] 'to move it.F'; $c f$. mogui ['moy-i] '(s)he moves.SUBJ', moguent [mu'yen] 'moving', mogut [mu'yut] 'moved'). We hypothesize that this case of root allomorphy is also the consequence of stress shift together with a specific markedness constraint against /w/ in the onset position of a stressed syllable, $*_{{ }_{\sigma}}[\mathrm{w}$, defined in (34).

(34) $*_{i_{\sigma}}[\mathrm{W}$

Assign one violation mark for every labiovelar glide [w] syllabified in the onset position of a stressed syllable.

This markedness constraint might seem language-specific, but it is wellknown that onsets of higher sonority are dispreferred cross-linguistically, and that markedness constraints can refer to specific prosodic contexts. ${ }^{19}$ This markedness constraint is never violated in Catalan verbal forms with available allomorphs, and is responsible for alternations such as those illustrated in (35). In the first and second plural forms of the present indicative stress is final. In such cases, in order to prevent forms with [w] in the onset position of a stressed syllable, the last consonant of the verbal root is $[\beta]$ in Central Catalan. All forms of the present subjunctive, as well as the gerund and the participle (leaving aside some highly

19. In nominal forms, the constraint $*_{{ }_{\sigma}}[\mathrm{W}$ is also active. It is always satisfied whenever a root ending in /-w/ has an allomorph ending in /-b/ (in Central Catalan) or /-v/ (in Balearic Catalan) (e.g. bla [w]

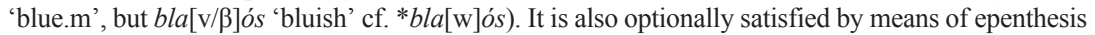
of a voiced velar stop [g] when output contiguity would not be altered, that is, in word-initial position (e.g. [g]whisky cf. *[w]hisky, but cali[w] 'embers' and acali[w]at 'reduced to embers' cf. *acali[yw]at). In denominal verbs like creuar [krə'wa] 'to cross', the constraint * ${ }^{\circ}[\mathrm{w}$ is violated in stressed syllables because the verb does not have an alternative available allomorph. 
irregular verbs), take the root allomorph ending in /-g/, which surfaces as [y] due to post-sonorant spirantization. For other verbs, roots ending in [w] alternate with roots ending in [j] (35b) (another case of root allomorphy). In Balearic Catalan, the first and second plural forms of these verbs are instead monosyllabic: ['səjm] and ['səjs]. What is crucial is the fact that forms like *[bə'wəm] or *[sə'wəw] are banned in all dialects of Catalan, and that the markedness constraint $*_{{ }_{\sigma}}[\mathrm{w}$ is surface-true in Catalan verbs.

(35) Alternations triggered by the satisfaction of $*_{1}[\mathrm{w}$ in Central and Balearic Catalan verbal forms

\begin{tabular}{|c|c|c|c|}
\hline \multicolumn{2}{|c|}{ 1. PI ('to drink') } & \multicolumn{2}{|c|}{ b. PI ('to sit down') } \\
\hline$b e c$ & ['bek] / ['bək] & $\sec$ & ['sck] \\
\hline beus & ['bews] / ['bəws] & seus & ['scws] \\
\hline beu & {$[$ 'bew $] /$ ['bəw] } & seu & ['sew] \\
\hline bevem & [bə' $\beta \varepsilon \mathrm{cm}] /$ ['bəjm] & seiem & [sə'j jem] / ['səjm] \\
\hline beveu & [bə' $\beta \varepsilon w]$ / ['bəjs] & seieu & [sə'jहw] / ['səjs] \\
\hline beuen & ['bewən] / ['bəwən] & seuen & ['scwən] \\
\hline
\end{tabular}

The stress shift motivated by enclisis would cause a violation of the markedness constraint $*_{{ }_{\sigma}}[\mathrm{W}$ in those verbs whose root ends in the labiovelar /-w/: *[mu'w-ər $=l$ lə].

The question now is how to account for the actual repaired form [mu'y-ər $=1$ ] ]. One possibility is to interpret the change as the result of a phonological process of strengthening, as suggested by an anonymous reviewer. One problem with this approach is that it is difficult to justify why the outcome is a velar consonant [y] instead of a labial [v]. An alternative approach is to relate the consonant change to root allomorphy. These verbs do have an allomorph with $/ \mathrm{g} /(\mathrm{mog} /)$ but also an allomorph with $/ \mathrm{v} /(/ \mathrm{mov} /)$. The allomorph with $/ \mathrm{v} /$ is found in the Imperfective Indicative (e.g. movia) and in first and second person plural of the present indicative (e.g. movem, moveu), while the allomorph with $/ \mathrm{g} /$ is found in the subjunctive (e.g. mogui), the impersonal forms (e.g. moguent 'moving', mogut 'moved') and the first person present indicative (e.g. moc, with final devoicing), as well as some forms of the now archaic synthetic form of the past indicative (e.g. mogueres [mu'yerəs] 'you moved'). The choice of the allomorph with /g/ could be attributed to two different explanations, one of them being a frequency effect, given that the allomorph with $/ \mathrm{g} /$ is found in more forms of the conjugation than the allomorph with $/ \mathrm{v} /$. The other explanation would be related to morphosyntactic factors. The allomorph with $/ \mathrm{g} /$ is found in the other non-personal forms, gerund and participle, while the allomorph with $/ \mathrm{v} /$ is found only in personal forms in EC and shares no morphosyntactic features with the infinitive. We leave for further research the exact formalization of this line of approach. 


\section{Conclusions}

In most Balearic varieties there is stress shift with pronominal enclisis (in infinitives and imperatives). In Eivissan Catalan, however, stress shift is found only in penultimately-stressed second conjugation infinitives, not in infinitives of other conjugations or imperatives. In isolation, most second conjugation infinitives surface with paroxytonic stress (e.g. [mə'rəə] 'to deserve'; ['romprə] 'to break'; [ən'sendrə] 'to turn on, to light'), contrary to all other infinitives, which are oxytonic. With enclisis, stress shifts one syllable to the right irrespective of the number of enclitics following the second conjugation infinitive (e.g. [mərə' 'ər $^{\prime}=$ tə] 'to deserve you'; [mərə' $\partial^{\circ}=$ tə $=1$ ə] 'to deserve it for you'). In first and third conjugation infinitives followed by enclitics, which surface with final stress without clitics, there is no stress shift (e.g. [kən'tar $=$ to $=$ lə] 'to sing it to you'; $\left[\mathrm{ku}\right.$ 'zir $=\mathrm{t}^{\mathrm{a}}=\mathrm{l}$ ] ] 'to sew it for you'). In this system, stress shift is circumscribed to affect only one conjugation class of infinitives; stress shift is strictly local, that is, stress only shifts one syllable to the right, and stress never falls on pronominal enclitics. This pattern contrasts with that of Formenteran Catalan, a closely related variety in which stress shifts to the penultimate syllable of the verb-clitic structure if it ends in a vowel and to the final syllable if it ends in a consonant in both

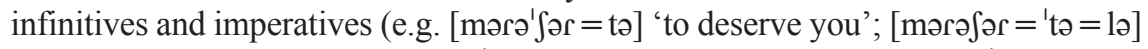
'to deserve it for you'; [kəntər = 'tə $=1$ b] 'to sing it to you'; [kuzir = 'tə $=$ lə] 'to sew it for you'). The pattern described for Formenteran Catalan is parallel to the one described for Lucanian, Italo-Romance (Peperkamp 1997), but the pattern of enclitic-triggered stress shift in Eivissan Catalan has never been described before. In this paper we have proposed an OT analysis of the prosodification of verb-clitic structures in Eivissan Catalan based on recursive adjunction, following Itô \& Mester (2009) (similar to the analysis of Neapolitan in Peperkamp 1997). The result is the following prosodic structure: $\left.\left((\text { inf })_{\omega} c l\right)_{\omega}\right)_{\varphi}$, in which there is a maximal prosodic word that contains the clitic(s) and a minimal prosodic word that contains the verbal host. At the same time, the constraint ranking for unmarked stress assignment in Catalan, which builds a right-aligned moraic trochee within the domain of the minimal prosodic word, is responsible for stress shift in second conjugation verbs. Finally, this paper has also accounted for the allomorphy found in second conjugation infinitives when followed by enclitics. Three types of second conjugation infinitives exist in Eivissan Catalan and most other dialects: those that end in [-ə(r)], those that end in [-rə], and those that end in [-d-rə], with an epenthetic [d]. As seen, [ə(ケ)]-ending infinitives have stress on the last syllable of the verbal stem with enclitics. Interestingly, all other second conjugation infinitives under encliticization surface as if they were [ə(r)]-ending verbs (e.g. [rum'p-ər $=$ tə] 'to break you', but ['romp-rə] 'to break'; [ənsə'n-ər $=$ tə] 'to turn on/to light to you', but [ən'sen-drə] 'to turn on/to light'). A distinct case of allomorphy in second conjugation infinitives whose root ends in $/ \mathrm{w} /$ is also accounted for. A constraint against $[\mathrm{w}]$ in the onset position of a stressed syllable in verbs induces, in the context of enclisis, the selection of a root allomorph that ends in $/ \mathrm{g} /$, which is also found in the other non-personal forms of the verb. 


\section{References}

Anderson, Stephen. 2011. Clitics. In van Oostendorp, Marc, Ewen, Colin, Hume, Elizabeth \& Rice, Keren (eds.). The Blackwell Companion to Phonology, 539559. Malden, MA: Blackwell.

Bennett, Ryan. 2018. Recursive prosodic words in Kaqchikel (Mayan). Glossa: A journal of general linguistics 3(1): 67. $<$ https://doi.org/10.5334/gjgl.550>

Bonet, Eulàlia \& Lloret, Maria-Rosa. 1998. Fonologia catalana. Barcelona: Ariel.

Bonet, Eulàlia \& Mascaró, Joan. 1997. On the representation of contrasting rhotics. In Martínez-Gil, Fernando \& Morales-Front, Alfonso (eds.). Issues in the phonology and morphology of the major Iberian languages, 103-126. Washington D.C.: Georgetown University Press.

Bonet, Eulàlia \& Torres-Tamarit, Francesc. 2010. Allomorphy in pre-clitic imperatives in Formenteran Catalan: An output-based analysis. In Colina, Sonia, Olarrea, Antxon \& Carvalho, Ana Maria (eds.). Romance Linguistics 2009. Selected papers from the 39th Linguistic Symposium on Romance Languages, 337-352. Amsterdam: John Benjamins. $<$ https://doi.org/10.1075/cilt.315>

Bonet, Eulàlia \& Torres-Tamarit, Francesc. 2011. Les formes d'imperatiu seguides de clític: un cas de conservadorisme lèxic. In Lloret, Maria-Rosa \& Pons-Moll, Clàudia (eds.). Noves aproximacions a la fonologia i la morfologia del català, 37-61. Alacant: Institut Interuniversitari de Filologia Valenciana.

Elfner, Emily. 2011. Syntax-prosody interactions in Irish. Doctoral dissertation, University of Massachusetts, Amherst.

Elfner, Emily. 2015. Recursion in prosodic phrasing: Evidence from Connemara Irish. Natural Language \& Linguistic Theory 33 (4): 1169-1208.

Itô, Junko \& Mester, Armin. 2007. Prosodic adjunction in Japanese compounds. In Miyamoto, Yoichi \& Ochi, Masao (eds.). Formal Approaches to Japanese Linguistics (FAJL) 4, 97-111. Cambridge, MA: MITWPL.

Itô, Junko \& Mester, Armin. 2009. The extended prosodic word. In Grijzenhout, Janet \& Kabak, Baris (eds.). Phonological domains: Universals and deviations, 135-194. Berlin \& New York: Mouton de Gruyter.

Itô, Junko \& Mester, Armin. 2012. Recursive prosodic phrasing in Japanese. In Borowsky, Toni, Kawahara, Shigeto, Shinya, Takahito \& Sugahara, Mariko (eds.). Prosody matters: Essays in honor of Elisabeth Selkirk, 280-303. London: Equinox.

Itô, Junko \& Mester, Armin. 2013. Prosodic subcategories in Japanese. Lingua 124: $20-40$. $<$ https://doi.org/10.1016/j.lingua.2012.08.016>

Kager, René \& Martínez-Paricio, Violeta. 2015. The binary-to-ternary rhythmic continuum in stress typology: Layered feet and non-intervention constraints. Phonology 32 (3): 459-504.

Kaisse, Ellen. 2017. The domain of stress assignment: Word-boundedness and frequent collocation. In Bowern, Claire, Horn, Laurence \& Zanuttini, Raffaella (eds.). On looking into words (and beyond), 17-41. Berlin: Language Science Press. $<$ https://doi.org/10.5281/zenodo.495437>

Kawahara, Shigeto. 2007. Copying and spreading in phonological theory: Evidence from echo epenthesis. In Bateman, Leah, O’Keefe, Michael, Reilly, Ehren \& 
Werle, Adam (eds.). Papers in Optimality Theory III (University of Massachusetts Occasional Papers in Linguistics 32). GSLA Publications.

Marí Tur, Roser. 2017. El segment velar en la flexió verbal de l'eivissenc: Anàlisi de la variació distribucional, geogràfica i generacional. Doctoral dissertation, Universitat de Barcelona.

Martínez-Paricio, Violeta. 2012. An Exploration of minimal and maximal metrical feet. Doctoral dissertation, University of Tromsø-Arctic University of Norway.

Mascaró, Joan. 1985. Morfologia. Barcelona: Enciclopèdia Catalana.

McCarthy, John J. 2005. Optimal paradigms. In Downing, Laura, Hall, T. Alan \& Raffelsiefen, Renate (eds.). Paradigms in phonological theory, 170-210. New York: Oxford University Press.

McCarthy, John J. \& Prince, Alan. 1993. Generalized alignment. Yearbook of Morphology 12. Retrieved from $<$ https://scholarworks.umass.edu/linguist_faculty_ pubs/12>.

Mascaró, Joan. 2007. External allomorphy and lexical representation. Linguistic Inquiry 38(4): 715-735.

McCarthy, John. 2008. Doing Optimality Theory: Applying theory to data. Malden, MA: Blackwell.

Nadeu, Marianna, Simonet, Miquel \& Llompart, Miquel. 2016. Stressed postverbal pronominals in Catalan. Probus 29(1): 119-162.

Nespor, Marina \& Vogel, Irene. 1986. Prosodic Phonology. Dordrecht: Foris.

Ortmann, Albert. 1999. Affix repetition and non-redundancy in inflectional morphology. Zeitschrift für Sprachwissenschaft 18(1): 76-120.

Peperkamp, Sharon. 1997. Prosodic words (HIL dissertations 34). The Hague: Holland Academic Graphics.

Pons-Moll, Clàudia. 2011. It is all downhill from here: A typological survey of the role of Syllable Contact in Romance languages. Probus 23(1): 105-173.

Repetti, Lori. 2016. The phonology of postverbal pronouns in Romance languages. In Tortora, Christina, den Dikken, Marcel, Montoya, Ignacio \& O’Neill, Teresa (eds.). Romance Linguistics 2013. Selected papers from the 43rd Linguistic Symposium on Romance Languages, 361-378. Amsterdam: John Benjamins. $<$ https://doi.org/10.1075/rllt.9.19rep>

Ribas Tur, Maria. 2018. La realització de les formes verbals seguides d'enclitics en eivissenc. Unpublished undergraduate thesis, Universitat Autònoma de Barcelona.

Selkirk, Elisabeth. 1981. On the nature of phonological representation. In Anderson, John, Laver, John \& Myers, Terry (eds.). The cognitive representation of speech, 379-388. Amsterdam: North Holland.

Selkirk, Elisabeth. 1984. Phonology and syntax: The relation between sound and structure. Cambridge, MA: MIT Press.

Selkirk, Elisabeth. 1995. The prosodic structure of function words. In Beckman, Jill, Walsh Dickey, Laura \& Urbanczyk, Suzanne (eds.). University of Massachusetts occasional papers 18: papers in Optimality Theory, 439-469. Amherst, MA: GLSA.

Selkirk, Elisabeth. 2009. On clause and intonational phrase in Japanese: The syntactic grounding of prosodic constituent structure. Gengo Kenkyu (Journal of the Linguistic Society of Japan) 136: 35-73. 
Selkirk, Elisabeth. 2011. The syntax-phonology interface. In Goldsmith, John, Riggle, Jason \& Yu, Alan. The Handbook of Phonological Theory, 435-484. Oxford: Blackwell.

Steriade, Donca. 1999. Lexical conservatism in French adjectival liaison. In Bullock, Barbara, Authier, Jean-Marc \& Reed, Lisa (eds.). Formal Perspectives in Romance Linguistics, 243-270. Amsterdam: John Benjamins.

Steriade, Donca. 2008. A pseudo-cyclic effect in Romanian morphophonology. In Bachrach, Asaf \& Nevins, Andrew (eds.). Inflectional identity, 313-360. Amsterdam: John Benjamins.

Torres-Tamarit, Francesc \& Pons-Moll, Clàudia. 2019. Enclitic-induced stress shift in Catalan. Journal of Linguistics 55: 407-444.

van der Hulst, Harry. 2010. A note on recursion in phonology. In van der Hulst, Harry (ed.). Recursion and human language, 301-342. Berlin \& New York: Mouton de Gruyter.

Vigário, Marina. 2010. Prosodic structure between the prosodic word and the phonological phrase: Recursive nodes or an independent domain? The Linguistic Review 27: 485-530.

$<$ https://doi.org/10.1515/tlir.2010.017>

Vogel, Irene. 2009. The status of the clitic group. In Grijzenhout, Janet \& Kabak, Baris (eds.). Phonological domains: Universals and deviations, 15-46. Berlin \& New York: Mouton de Gruyter. 